\title{
TINDAK TUTUR DIREKTIF WACANA BERITA ONLINE: KAJIAN MEDIA PEMBELAJARAN BERBASIS TEKNOLOGI DIGITAL
}

\author{
Sri Waljinah', Harun Joko Prayitno², Eko Purnomo ${ }^{3}$, Ani Rufiah ${ }^{4}$, \\ Erry Widya Kustanti ${ }^{5}$ \\ Universitas Muhammadiyah Surakarta 1,2,3,4,5 \\ Posel:sw122@ums.ac.id; hip220@ums.ac.id; eko97purnomo@gmail.com; \\ ani.rufiah17@gmail.com; errywidya022@gmail.com
}

\begin{abstract}
This study aims to identify directive speech acts on online news titles. Research data are sentences in online news titles. Research data sources in the form of online news titles sourced from the news in CNN Indonesia, Liputan 6.com, Detiknews, Viva.co.id.news, TEMPO.CO, Kompas.com, Kumparan.News, and Republika.co.id. Data collection using documentation methods, see, and note technique. Analysis of research data using the intralingual and pragmatic matching methods. The validity of the data in this study uses the triangulation method. The results showed the directive speech acts in the online news titles included: (1) forcing as much as $3.2 \%$; (2) request as much as $4 \%$; (3) asking for $40 \%$; (4) giving orders as much as $2.4 \%$; (5) demanded $4.8 \%$; (6) prohibiting $12.8 \%$; (7) suggest $11.2 \%$; (8) invite 16\%; and (9) collect 5.6\%. The directive speech act on the online news headline can be used as a learning medium in digital technology-based schools.
\end{abstract}

Keywords: directive speech acts; online news; learning media; digital technology.

\begin{abstract}
Abstrak
Penelitian ini bertujuan mengidentifikasi tindak tutur direktif pada judul berita online. Data penelitian yaitu kalimat-kalimat pada judul berita online. Sumber data penelitian berupa judul berita online yang bersumber pada pemberitaan dalam CNN Indonesia, Liputan 6.com, Detiknews, Viva.co.id.news, TEMPO.CO, Kompas.com, Kumparan.News, dan Republika.co.id. Pengumpulan data menggunakan metode dokumentasi, simak, dan teknik catat. Analisis data penelitian menggunakan metode padan intralingual dan pragmatis. Keabsaan data dalam penelitian ini menggunakan metode trianggulasi. Hasil penelitian menunjukkan wujud tindak tutur direktif pada judul berita online meliputi: (1) memaksa sebanyak $3,2 \%$; (2) memohon sebanyak 4\%; (3) meminta sebanyak $40 \%$; (4) memberi perintah sebanyak $2,4 \%$; (5) menuntut sebanyak $4,8 \%$; (6) melarang sebanyak $12,8 \%$; (7) menyarankan sebanyak $11,2 \%$; (8) mengajak sebanyak $16 \%$; dan (9) menagih sebanyak $5,6 \%$. Tindak tutur direktif pada judul berita online dapat digunakan sebagai media pembelajaran di sekolah berbasis teknologi digital.
\end{abstract}

Kata Kunci: tindak, tutur direktif; berita online; media pembelajaran; teknologi digital.

\section{PENDAHULUAN}

Bahasa merupakan sarana komunikasi yang sangat penting dalam kehidupan manusia. Wiranty (2015:13) mengemukakan bahasa adalah salah satu alat komunikasi, karena melalui bahasa manusia dapat saling berhubungan (berkomunikasi), berbagi pengalaman, belajar dari orang lain, dan meningkatkan kemampuan intelektual. Ananda dkk. (2015:2) mengemukakan bahwa segala aktivitas tidak terlepas dari penggunaan bahasa. Selaras dengan pendapat tersebut, Nirmala (2015:139) mengemukakan bahwa komunikasi merupakan proses menyampaikan pesan dari komunikator kepada komunikan melalui media tertentu secara langsung atau tidak langsung untuk tujuan tertentu. 
Bahasa dalam ilmu linguistik yang mempelajari maksud penutur berdasarkan konteks disebut pragmatik. Nadar (2009:2) mengemukakan suatu cabang ilmu dalam linguistik yang mempelajari bahasa yang digunakan untuk berkomunikasi dalam situasi tertentu disebut pragmatik. Pragmatik memusatkan perhatian pada cara insan berperilaku dalam keseluruhan situasi pemberian dan penerimaan tanda (Tarigan, 2009:33). Pragmatik adalah salah satu cabang ilmu bahasa yang mempelajari makna yang berkaitan dengan konteks. Hal tersebut selaras dengan pandangan Wijana yaitu pragmatik mengkaji makna yang terikat dengan konteks (Nadar, 2009:4). Dengan demikian, konteks tidak hanya mengacu pada ungkapan verbal sebagai konteks lingual, namun juga pada konteks nonlingual.

Pragmatik (semantik behavioral) menelaah keseluruhan perilaku manusia yang berkaitan dengan tanda-tanda dan lambang-lambang dalam bentuk tindak tutur. Ardiansyah dkk. (2014:23) mengemukakan bahwa konteks mengacu pada siatuasi atau kondisi ketika tuturan diujarkan. Oleh karena itu, kajian pragmatik tidak dapat terlepas dari konteks tuturan karena konteks berperan sebagai tolak ukur dalam menentukan makna. Rohmadi (2014:21) mengemukakan tindak tutur sangat berkaitan dengan situasi konteks. Selaras dengan itu, Basuki (2013:3-4) mengemukakan konteks digunakan untuk mengacu pada pemahaman antar penutur dan mitra tutur tentang pengetahuan, pengalaman, persoalan, yang dipraanggapkan, situasi waktu, tempat, dan peristiwa. Yule (2014:31) mengatakan bahwa tindakan-tindakan yang ditampilkan lewat tuturan disebut tindak tutur.

Tindak tutur merupakan gejala yang terdapat pada suatu proses komunikasi dalam menyampaikan atau menyebutkan suatu maksud oleh penutur kepada mitra tutur. Tindak tutur adalah tuturan atau sesuatu yang dikatakan oleh penutur sembari melakukan suatu tindakan yang bermakna tertentu untuk memperoleh respon yang diharapkan dari mitra tutur. Tindak tutur yang dipilih bergantung pada beberapa faktor yang berkaitan dengan fungsi bahasa sebagai sarana penyampai pesan. Tindak tutur berkaitan dengan fungsi bahasa dikemukakan oleh Leech (Mardikantoro, 2014:216), yaitu fungsi informatif, ekspresif, direktif, estetis, dan fatis. Fungsi informatif merupakan fungsi utama dalam proses komunikasi karena sebagai penyampai pesan kepada mitra tutur. Hal tersebut senada dengan pendapat Chaer dan Leonie Agustina yaitu tindak tutur merupakan gejala individual, bersifat psikologis, dan keberlangsungannya ditentukan oleh kemampuan bahasa penutur dalam menghadapi situasi tertentu (Purba, 2011:80). Selaras dengan pendapat tersebut, Laksono dan Supeli mengemukakan bahwa tiap kata pada dasarnya adalah penyalur gagasan yang di dalamnya terkandung sebuah makna yang hendak dilanjutkan kepada orang lain atau mitra tutur (Prayitno, 2017:40).

Tindak tutur merupakan rangkaian kata-kata bermakna yang terangkum dalam wacana. Sobur (2015:10) mengemukakan wacana merupakan rangkaian tindak tutur yang mengungkapkan suatu hal atau subjek yang disajikan secara teratur dan sistematis dalam satu kesatuan yang koheren dan dibentuk berdasarkan unsur segmental dan suprasegmental. Berdasarkan hal tersebut, wacana mempengaruhi mitra tutur untuk melakukan sesuatu yang diinginkan oleh penutur karena tindak tutur memiliki maksud yang akan disampaikan kepada mitra tutur. Safrihady (2017:60) menyatakan bahwa maksud dalam tindak tutur perlu dipertimbangkan dengan berbagai kemungkinan tindak tutur yang 
sesuai dengan posisi penutur, situasi tutur, dan kemungkinan struktur yang ada dalam bahasa itu.

Penutur cenderung menggunakan bahasa seperlunya dalam berkomunikasi. Pemilihan bahasa oleh penutur lebih mengarahkan pada bahasa yang komunikatif. Melalui konteks situasi yang jelas suatu peristiwa komunikasi dapat berjalan dengan lancar. Tuturan diutarakan oleh penutur dilatarbelakangi oleh maksud dan tujuan tertentu. Bentuk-bentuk tuturan yang bermacam-macam dapat digunakan untuk menyatakan maksud yang sama (Handono dkk, 2013:18). Tindak tutur memiliki berbagai tujuan yang ingin disampaikan penutur kepada mitra tuturnya sehingga dapat dibagi menjadi beberapa jenis sesuai dengan tujuan penutur. Searle membagi tindak tutur menjadi tiga jenis yaitu lokusi, ilokusi, dan perlokusi (Prayitno, 2017:49). Leech membagi tindak tutur menjadi enam, yaitu: asertif, direktif, komisif, ekspresif, deklaratif, dan rogatif (Prayitno, 2017:51). Menurut Handono dkk. (2013:61) tindak tutur bertujuan untuk menyampaikan informasi, mengkritik, memberi saran, mengajak, memerintah, dan memberi janji-janji.

Tindak tutur direktif perlu dilengkapi dengan peranti penyelamat muka berupa kesopanan (politeness) berbahasa. Hal ini berkaitan dengan pendapat Brown dan Levinson yang mengemukakan bahwa tindak tutur direktif memiliki kecenderungan untuk menjatuhkan muka mitra tuturnya (Manaf, 2011:212). Leech mengemukakan bahwa tindak tutur direktif adalah bentuk tutur yang dimaksudkan oleh penutur untuk membuat pengaruh agar mitra tutur melakukan suatu tindakan yang mencakup sub tindak tutur memohon, meminta, memberi perintah, menuntut, dan melarang (Prayitno, 2017:51). Hal ini selaras dengan pendapat Searle (dalam Ibrahim, dkk., 2012) yaitu wujud tutur berkaitan erat dengan tindak tutur, fungsi tutur, dan strategi bertutur.

Kajian dalam penelitian ini adalah tindak tutur direktif dalam wacana judul berita online yang dikembangkan sebagai media pembelajaran berbasis digital. Pemanfaatan tindak tutur direktif dalam wacana judul berita online sebagai media pembelajaran berkaitan dengan era digital saat ini. Fuzan (dalam Ibda, 2018:5-6) menyatakan bahwa model dari Industri 4.0 adalah kombinasi dari beberapa perkembangan teknologi terbaru seperti sistem siber fisik, teknologi informasi dan komunikasi, jaringan komunikasi, big data, cloud computing, pemodelan, virtualisasi, simulasi serta peralatan untuk kemudahan interaksi manusia dengan komputer. Dalam proses belajar mengajar, lima komponen yang sangat penting adalah tujuan, materi, metode, media, dan evaluasi pembelajaran (Falahudin, 2014:12).

Penelitian tentang tindak tutur dalam pembelajaran dilakukan oleh Ratnasari dan Edel (2017) yaitu tindak tutur pada novel yang meliputi 10 tindak tutur asertif, 12 tindak tutur direktif, 6 tindak tutur komisif, 13 tindak tutur ekpresif, dan 1 tindak tutur deklarasi. Qomariyah (2017) meneliti tindak tutur guru dalam pembelajaran Bahasa Arab yang mengkategorikan TTD guru dalam pembelajaran bahasa Arab di MAN 1 Jombang meliputi tindak tutur requestives meminta, requestives mendoa, requestives mengajak, questions bertanya, questions menyelidik, requirements memerintah, requirements mengarahkan, probibitives melarang, permissives membolehkan, advisories menyarankan, dan advisories mendorong.

Tindak tutur direktif banyak terkandung dalam judul berita online karena memiliki maksud yang dapat menimbulkan reaksi atau efek bagi pembacanya. Fungsi informatif memiliki peran utama dalam wacana berita online yaitu sebagai alat penyampai informasi 
kepada masyarakat. Berita adalah laporan mengenai fakta dan pendapat yang penting dan menarik bagi sebagian khalayak dan harus dipublikasikan secepatnya kepada khalayak (Kusmanto, 2019:35). Salah satu cara yang digunakan untuk mempublikasikan berita secara cepat dengan media digital yaitu berita online.

Penelitian tentang tindak tutur direktif pada judul berita online belum pernah dilakukan pada kajian sebelumnya. Oleh karena itu, penelitian ini menarik untuk dilakukan karena mengidentifikasi tindak tutur direktif pada judul berita online yang dapat dikembangkan sebagai media pembelajaran di sekolah yang kreatif dan inovatif dengan berbasis teknologi digital. Berdasarkan latar belakang tersebut, maka dirumuskan permasalahan sebagai berikut: (1) bagaimana tindak tutur direktif dalam judul berita online?; dan (2) bagaimana tindak tutur direktif dalam judul berita online sebagai media pembelajaran berbasis teknologi digital?

\section{METODE PENELITIAN}

Jenis penelitian ini menggunakan pendekatan deskriptif kualitatif. Data yang dianalisis berupa kata-kata (Mahsun, 2014:257). Data dalam penelitian ini berupa kalimat-kalimat pada judul berita online yang memiliki penanda tindak tutur direktif. Sumber data dalam penelitian ini berupa judul berita online yang diberitakan dalam CNN Indonesia, Liputan 6.com, Detiknews, Viva.co.id.news, TEMPO.CO, Kompas.com, Kumparan.News, dan Republika.co.id.

Penelitian ini dilakukan pada bulan Juni sampai dengan Juli tahun 2019. Teknik pengumpulan data menggunakan metode dokumentasi dan teknik catat. Analisis data menggunakan metode padan intralingual (Mahsun, 2014) dan padan pragmatis (Sudaryanto, 2015:18). Metode padan intralingual digunakan untuk mengidentifikasi wujud tindak tutur direktif pada judul berita online. Metode padan pragmatis digunakan untuk menentukan konteks tuturan.

\section{HASIL PENELITIAN DAN PEMBAHASAN}

\section{Tindak Tutur Direktif dalam Judul Berita Online}

Tindak tutur direktif pada judul berita online diklasifikasi menjadi 9 (sembilan), yaitu tindak tutur direktif memaksa, memohon, meminta, memberi perintah, menuntut, melarang, menyarankan, mengajak, dan menagih. Distribusi tindak tutur direktif pada judul berita online disajikan pada tabel berikut ini.

Tabel 1.

Distribusi Tindak Tutur Direktif pada Judul Berita Online

\begin{tabular}{clcc}
\hline No. & \multicolumn{1}{c}{ Tindak Tutur Direktif } & Jumlah Data & Presentase \\
\hline 1 & Memaksa & 4 & $3,2 \%$ \\
2 & Memohon & 5 & $4 \%$ \\
3 & Meminta & 50 & $40 \%$ \\
4 & Memberi Perintah & 3 & $2,4 \%$ \\
5 & Menuntut & 6 & $4,8 \%$ \\
6 & Melarang & 16 & $12,8 \%$ \\
7 & Menyarankan & 14 & $11,2 \%$ \\
8 & Mengajak & 20 & $16 \%$ \\
9 & Menagih & 7 & $5 \%$ \\
& & 125 & $100 \%$ \\
\hline
\end{tabular}


Berdasarkan tabel di atas, maka tindak tutur direktif pada judul berita online diuraikan sebagai berikut.

\section{a. Tindak Tutur Direktif Memaksa}

Tindak tutur direktif memaksa bertujuan untuk melakukan sesuatu hal dengan paksaan. Penanda tindak tutur deklaratif memutuskan pada judul berita online dibagi menjadi dua penanda. Kedua penanda tidak tutur direktif pada judul berita online meliputi penanda paksa dan penanda memaksa. Tindak Tutur direktif memaksa dideskripsikan sebagai berikut.

\section{1) Tindak Tutur Direktif Memaksa dengan Penanda Paksa}

Tindak tutur direktif memaksa bertujuan untuk memaksa suatu hal. Tindak tutur direktif berpenanda paksa pada judul berita online bertujuan untuk memaksa seseorang melakukan sesuatu secara paksa. Tidak tutur direktif memaksa berpenanda paksa dicuplikkan dari CNN Indonesia tanggal 15 Juli 2019, yaitu: Polisi Panggil Paksa Sopir Rubicon Penabrak Panitia Maraton.

Konteks judul di atas yaitu 'Kasubdit Gakkum Ditlantas Polda Metro Jaya AKBP M. Nasir mengatakan polisi telah mengirim surat pemanggilan kepada pengendara Rubicon itu, namun PDK tidak berada di rumahnya yang terletak di daerah Menteng, Jakarta Pusat'. Tuturan pada data di atas merupakan bentuk tindak tutur direktif memaksa. Penanda paksa pada judul berita online di atas menunjukkan bentuk direktif memaksa. Penanda paksa tersebut merupakan tindakan memaksa kepada pengendara Jeep Rubicon untuk hadir memberi kesaksian kepada pihak kepolisian, karena telah menabrak panitia marathon dan melarikan diri pada saat kejadian.

\section{2) Tindak Tutur Direktif Memaksa dengan Penanda Memaksa}

Tindak tutur direktif memaksa bertujuan untuk memaksa suatu hal. Tindak tutur direktif berpenanda memaksa pada judul berita online bertujuan untuk memaksa seseorang melakukan sesuatu dengan pemaksaan. Tidak tutur direktif memaksa berpenanda memaksa pada judul berita online dicuplikkan dari Viva.co.id.news pada tanggal 22 Juni 2019, yaitu: Memaksa Cium Hajar Aswad, Jemaah Indonesia Terluka.

Konteks pada cuplikan berita di atas yaitu 'Tim Pertolongan Pertama Pada Jemaah Haji (P3JH) bersama Tim Sektor Khusus Masjidil Haram menemukan dua orang jemaah haji terluka karena memaksakan diri mencium hajar aswad, Senin, 22 Juli 2019, sekira pukul 10.00 waktu Arab Saudi karena terinjak-injak disekitar area thawaf. Penanda memaksa pada judul berita online di atas menunjukkan bentuk direktif memaksakan diri. Penanda memaksa ditunjukkan oleh tindakan memaksa yang dilakukan oleh jamaah haji Indonesia untuk mencium Hajar Aswad, sehingga terluka karena terinjak-injak jamaah lainnya.

\section{b. Tindak Tutur Direktif Memohon}

Tindak tutur direktif memohon bertujuan untuk meminta sesuatu dengan hormat atau dengan sopan. Penanda tindak tutur deklaratif memutuskan pada judul berita online terdiri dari penanda harap dan permohonan. Tindak Tutur direktif memohon dideskripsikan sebagai berikut. 


\section{1) Tindak Tutur Direktif Memohon dengan Penanda Harap}

Tindak tutur direktif memohon bertujuan untuk meminta sesuatu dengan hormat. Tindak tutur direktif berpenanda memaksa pada judul berita online bertujuan untuk meminta agar kejadian kematian Haringga tidak terulang lagi. Tindak tutur direktif memohon dengan penanda harap pada judul berita online dicuplikkan dari CNN Indonesia pada tanggal 9 Juli 2019, yaitu: Jakmania Harap Tak. Ada Tragedi Haringga di Persija us Persib.

Konteks berita di atas yaitu 'Sekretaris Umum Jakmania memperingatkan pihak kepolisian untuk tidak lalai mengawasi pergerakan suporter dalam laga Persija Jakarta lawan Persib Bandung'. Tuturan di atas merupakan tindak tutur direktif dengan penanda harap pada pihak kepolisian agar lebih waspada dalam mengamankan suporter Persija dan Persib yang bertanding agar tidak terulang lagi kejadian meninggalnya suporter Persija Haringga.

\section{2) Tindak Tutur Direktif Memohon dengan Penanda Permohonan}

Tindak tutur direktif memohon dengan penanda permohonan bertujuan untuk meminta sesuatu dengan hormat. Tindak tutur direktif memohon dengan penanda permohonan ampun pada judul berita online dicuplikkan dari Kompas.com pada tanggal 15 Juli 2019, yaitu: Datangi Istana, Baiq Nuril Sampaikan Surat Permohonan Amnesti.

Konteks pada cuplikan berita di atas yaitu 'Baiq Nuril Maqnun korban pelecehan seksual yang justru divonis penjara karena perekaman ilegal, mendatangi Kompleks Istana Kepresidenan, Jakarta, Senin, 15 Juli 2019 untuk menyerahkan surat pengajuan amnesti kepada Presiden Joko Widodo'. Tuturan di atas merupakan pemberitaan tentang permohonan yang dilakukan oleh Baiq Nuril. Penanda kalimat direktif memohon terdapat pada kata 'permohonan' sebagai permintaan dengan hormat dari Baiq Nuril kepada Presiden Joko Widodo untuk memberi amnesti.

\section{c. Tindak Tutur Direktif Meminta}

Tindak tutur direktif meminta merupakan tuturan yang bertujuan untuk meminta sesuatu atau melakukan sesuatu atau bahkan melakukan sesuatu yang diperintahkan oleh penutur dan dijalankan oleh mitra tutur. Penanda tindak tutur deklaratif meminta pada judul berita online terdiri dari penanda wanti-wanti, minta, ingin, imbau, dan desak yang dideskripsikan sebagai berikut.

\section{1) Tindak Tutur Direktif Meminta dengan Penanda Wanti-wanti}

Tindak tutur direktif memohon dengan penanda wanti-wanti bertujuan untuk memberi pesan kepada mitra tutur agar melaksankaan dengan sungguh pesan yang disamapikan tersebut. Tindak tutur direktif memohon dengan penanda ampun pada judul berita online dicuplikkan dari Kumparan.News pada tanggal 22 Juli 2019, yaitu: PKS Yakin Amien Rais Oposisi: Beliau Wanti-Wanti P AN Tak MasukKabinet

Konteks berita di atas yaitu 'Wakil Ketua Majelis Syuro Partai Keadilan Sejahtera Hidayat Nur Wahid menanggapi pernyataan Ketua Dewan Kehormatan PAN Amien Rais soal pembagian kekuasaan 55-45 persen karena berkeyakinan bahwa Amien tetap akan menjadi oposisi dari pemerintahan Jokowi-Ma'ruf. Tuturan di atas merupakan pemberitaan tentang permintaan Amien Rais agar PAN tetap berada di oposisi pada pemerintahan 
Jokowi-Ma'ruf. Penanda kalimat direktif pada kata wanti-wanti yang disampaikan oleh Amien Rais agar PAN tetap berada pada posisi oposisi.

\section{2) Tindak Tutur Direktif Meminta dengan Penanda Minta}

Tindak tutur direktif memohon dengan penanda minta bertujuan agar mitra tutur melakukan atau memberikan sesuatu kepada penutur. Tindak tutur direktif memohon dengan penanda ampun pada judul berita online dicuplikkan dari Liputan 6.com pada tanggal 21 Juni 2019, yaitu: Usut Penyerangan Novel, Kompolnas Minta Polri Selisik. Kasus Buku Merah.

Konteks pada cuplikan berita di atas yaitu 'Anggota Komisi Kepolisian Nasional Andrea H. Poeloengan berpendapat, Polri harus menyelidiki kasus perobekan 'buku merah' dalam mengungkap penyerangan terhadap penyidik senior KPK, Novel Baswedan'. Tuturan di atas merupakan pemberitaan tentang permintaan Kapolnas meminta agar Polri mengusut kasus 'buku merah'. Penanda kalimat direktif meminta pada kata 'minta' yaitu permintaan Kapolnas pada Polri agar segera mengusut kasus yang menimpa Novel Baswedan.

\section{3) Tindak Tutur Direktif Meminta dengan Penanda Ingin}

Tindak tutur direktif meminta dengan penanda ingin bertujuan agar mitra tutur mau melakukan sesuatu. Tidak tutur direktif memohon dengan penanda ampun pada judul berita online dicuplikkan dari Viva.co.id.news pada tanggal 5 Juni 2019, yaitu: PKB Ingin Jatah Menteri PKB dan NU Berbeda.

Konteks pada cuplikan berita di atas yaitu 'Ketua DPP PKB, Abdul Karding menyakini, jatah kursi menteri PKB akan berbeda dengan Nahdatul Ulama, karena NU dan PKB sama-sama bekerja memenangkan Jokowi'. Tuturan di atas merupakan pemberitaan tentang permintaan agar Jokowi membedakan komposisi menteri untuk PKB dan NU. Penanda kalimat direktif meminta pada kata 'ingin' sebagai permintaan ketua DPP PKB Abdul Karding agar jatah menteri yang diberikan Jokowi ke PKB dan NU berbeda.

\section{4) Tindak Tutur Direktif Meminta dengan Penanda Imbau}

Tindak tutur direktif meminta dengan penanda imbau merupakan tindak tutur untuk mengimbau seseorang melakukan sesuatu dengan sungguh. Tindak tutur direktif memohon dengan penanda ampun pada judul berita online dicuplikkan dari CNN Indonesia pada tanggal 20 Juli 2019, yaitu: Bank Mandiri Gangguan Sistem, BI Imbau Nasabah Tidak Panik.

Konteks berita di atas yaitu 'Bank Indonesia (BI) mengimbau nasabah Bank Mandiri tidak panik meski perseroan mengalami gangguan sistem, sebab perusahaan telah menjamin keamanan dana nasabah'. Tuturan di atas menunjukkan penanda kalimat direktif meminta pada kata 'imbau' sebagai permintaan Bank Indonesia pada nasabah agar tetap tenang dan tidak panik terhadap berkurangnya dana nasabah.

\section{5) Tindak Tutur Direktif Meminta dengan Penanda Desak}

Tindak tutur direktif meminta dengan penanda desak merupakan tindak tutur untuk meminta seseorang melakukan dengan sangat. Tindak tutur direktif memohon dengan 
penanda ampun pada judul berita online dicuplikkan dari Republika.co.id pada tanggal 8 Juli 2019, yaitu: DPR Desak Pemerintah Selesaikan Soal Penurunan Tiket Pesawat.

Konteks berita di atas yaitu 'Ketua Dewan Perwakilan Rakyat (DPR) RI, Bambang Soesatyo menyoroti belum usainya pembahasan penurunan harga tiket untuk kategori maskaapi berbiaya rendah'. Tuturan di atas merupakan penanda kalimat direktif meminta yang terdapat pada kata 'desak' sebagai permintaan yang harus segera diselesaikan oleh pemerintah terkait dengan penurunan harga tiket untuk kategori maskapai berbiaya rendah.

\section{d. Tindak Tutur Direktif Memberi Perintah}

Tindak tutur direktif memberi perintah bertujuan untuk memberikan perintah kepada seseorang untuk melakukan atau melaksanakan sesuatu, biasanya dilakukan oleh orang yang memiliki jabatan lebih tinggi kepada orang yang memiliki jabatan di bawahnya. Tindak tutur direktif memberi perintah pada judul berita online dicuplikkan dari Liputan 6.com pada tanggal 27 Juli 2019, yaitu: Rodrigo Duterte Perintabkan Pengiriman Bantuan untuk Korban Gempa Filipina.

Konteks pada cuplikan berita di atas yaitu 'Presiden Rodrigo R. Duterte mengarahkan semua lembaga terkait untuk memberi bantuan kepada para korban gempa bumi Filipina bermagnitudo 5,4 dan 5,9 yang mengguncang Batanes pada Sabtu pagi'. Tuturan di atas merupakan pemberitaan tentang perintah yang dilakukan oleh Presiden Rodrigo R. Duterte untuk memberikan bantuan kepada korban gempa bumi Filipina.

\section{e. Tindak Tutur Direktif Menuntut}

Tindak tutur direktif menuntut merupakan tuturan yang bertujuan untuk meminta dengan keras supaya mitra tutur melakukan sesuatu yang harus dipenuhi oleh mitra tutur. Tindak tutur direktif memberi perintah pada judul berita online dicuplikkan dari CNN Indonesia pada tanggal 5 Juli 2019, yaitu: PSI Tuntut Transparansi Pemiliban Wakil Gubernur DKI.

Konteks berita di atas yaitu 'Partai Solidaritas Indonesia (PSI) Jakarta menuntut DPRD DKI, Gerindra, dan PKS, menjalankan transparansi dalam proses pemilihan Wakil Gubernur DKI Jakarta agar sosok yang terpilih dapat memenuhi kebutuhan warga ibu kota'. Tuturan di atas merupakan pemberitaan tentang tuntutan yang dilakukan oleh Partai Solidaritas Indonesia (PSI) agar DPRD DKI, Gerindra, dan PKS terbuka dalam proses pemilihan Wakil Gubernur pengganti Sandiaga Uno.

\section{f. Tindak Tutur Direktif Melarang}

Tindak tutur direktif melarang merupakan tuturan yang bertujuan melarang mitra tutur agar tidak melakukan suatu perbuatan tertentu. Penanda tindak tutur deklaratif melarang pada judul berita online meliputi penanda cegah, cekal, dan jangan. Tindak Tutur direktif melarang dideskripsikan sebagai berikut.

\section{1) Tindak Tutur Direktif Melarang dengan Penanda Cegah}

Tindak tutur direktif melarang dengan penanda cegah bertujuan untuk menahan atau merintai agar mitra tutur yang dituju tidak melakukan hal yang dilarang tersebut. Tindak 
tutur direktif memohon dengan penanda ampun pada judul berita online dicuplikkan dari Detiknews pada tanggal 19 Juli 2019, yaitu: KPK Cegah Staf Romaburmuriy ke Luar Negeri.

Konteks berita di atas yaitu 'KPK mengirimkan surat ke Ditjen Imigrasi Kemenkum HakAsasi Manusia (HAM) untuk mencegah staf Romahurmuziy (Rommy), Amin Nuryadi, ke luar negeri selama enam bulan'. Tuturan di atas merupakan pemberitaan tentang pencegahan yang dilakukan oleh KPK terhadap staf Romahurmuziy. Penanda kalimat direktif melarang terdapat pada kata 'cegah' sebagai larangan yang dilakukan oleh KPK terhadap staf Romahurmuziy agar tidak bepergian ke luar negeri selama enam bulan karena Amin merupakan saksi dalam kasus korupsi yang dilakukan oleh Romahurmuziy.

\section{2) Tindak Tutur Direktif Melaran dengan Penanda Cekal}

Tindak tutur direktif melarang dengan penanda cekal merupakan akronim dari penanda cegah bertujuan untuk menahan atau merintangi agar mitra tutur yang dituju tidak melakukan hal yang dilarang tersebut atau menangkal seseorang untuyk tidak dapat bebepergian. Tindak tutur direktif memohon dengan penanda ampun pada judul berita online dicuplikkan dari TEMPO.CO pada tanggal 1 Juli 2019, yaitu: Kasus Suap Kejati DKI, KPK Cekal Tiga Tersangka ke Luar Negeri.

Konteks berita di atas yaitu 'Komisi Pemberantasan Korupsi (KPK) mencekal tiga orang terkait kasus dugaan suap kepada Asisten Bidang Tindak Pidana Umum Kejaksaan Tinggi DKI Jakarta Agus Winoto'. Tuturan di atas merupakan pemberitaan tentang larangan bepergian ke luar negeri untuk tersangka kasus suap Kejati DKI Jakarta yang dilakukan oleh KPK. Penanda kalimat direktif melarang terdapat pada kata 'cekal' sebagai larangan untuk bepergian ke luar negeri Sendi Pericho, Tjhun Tje Min, dan seorang PNS bernama Aria Wira Suranta atas dugaan kasus suap Kejati DKI Jakarta.

\section{3) Tindak Tutur Direktif Melarang dengan Penanda Jangan}

Tindak tutur direktif melarang dengan penanda jangan merupakan sebuah larangan. Tindak tutur direktif memohon dengan penanda ampun pada judul berita online dicuplikkan dari Detiknews pada tanggal 16 Juli 2019, yaitu: Mendikbud soal Siswa SMA Taruna Tewas saat MOS: Sekolah Jangan Bikin Teror.

Konteks berita di atas yaitu 'Menteri Pendidikan dan Kebudayaan (Mendikbud) Muhadjir Effendy menyesalkan atas meninggalnya siswa SMA Taruna Indonesia, Palembang, Sumatera Selatan, Dewlyn Berli (14) saat MOS dengan mengatakan bahwa sekolah seharusnya membuat siswa nyaman dan jauh dari kekerasan'. Tuturan berita di atas merupakan pemberitaan tentang larangan sekolah untuk tidak melakukan teror kepada siswa baru. Penanda kalimat direktif melarang terdapat pada kata ‘jangan’ sebagai larangan kepada sekolah agar tidak ada kekerasan dalam MOS siswa baru.

\section{g. Tindak Tututr Direktif Menyarankan}

Tindak tutur direktif menyarankan merupakan tuturan yang bertujuan memberikan saran atau anjuran kepada mitra tutur yang dituju. Tindak tutur direktif memberi perintah pada judul berita online dicuplikkan dari Viva.co.id.news pada tanggal 18 Juli 2019, yaitu: DPR Sarankan Menteri Perdagangan Pergi ke China. 
Konteks berita di atas yaitu 'Wakil Ketua Komisi VI Dewan Perwakilan Rakyat, Inas Nasrullah Zubir mengatakan, Indonesia harus meningkatkan ekspor produksi, namun dia menjelaskan, ekspor pun ditingkatkan dengan mengirim barang suah siap pakai'. Tuturan di atas merupakan tindak tutur direktif menyarankan, yaitu saran dari Wakil Ketua Komisi VI DPR Inas Nasrullah Zubir agar menteri perdagangan pergi ke China untuk melakukan lobi dan mengetahui apa yang dibutuhkan oleh negara China.

\section{h. Tindak Tutur Direktif Mengajak}

Tindak tutur direktif mengajak merupakan tuturan yang bertujuan untuk meminta menyilakan, menyuruh, supaya mitra tutur menurut apa yang dikatakan oleh penutur. Tindak tutur direktif memberi perintah pada judul berita online dicuplikkan dari CNN Indonesia pada tanggal 7 Juli 2019, yaitu: Zulkifli Hasan Ajak Kader P AN Move on.

Konteks berita di atas yaitu 'Ketua Umum DPP Partai Amanat Nasional (PAN) mengajak seluruh kader PAN untuk bangkit atau move on dari pemilihan presiden 2019'. Tuturan di atas merupakan pemberitaan tentang ajakan Ketua Umum DPP PAN Zulkifli Hasan agar semua kadernya bangkit atau move on setelah pemilu presiden 2019.

\section{i. Tindak Tutur Direktif Menagih}

Tindak tutur direktif menagih merupakan tuturan yang bertujuan untuk meminta melaksanakan janji yang telah diucapkan mitra tutur. Tindak tutur direktif memberi perintah pada judul berita online dicuplikkan dari Detiknews pada tanggal 18 Juli 2019, yaitu: Warga Bandung Barat Terdampak Kereta Cepat Tagih Ganti Untung ke BPN.

Konteks berita di atas yaitu 'Puluhan warga terdampak Kereta Cepat Indonesia China (KCIC) di Kabupaten Bandung Barat geruduk Kantor Badan Pertanahan Nasioanal Bandung Barat di Jalan Raya Padalarang, Kamis (18/7/2019) siang'. Tuturan di atas merupakan pemberitaan tentang warga Bandung yang menagih ganti untung atas lahan warga yang terkena proyek Kereta Cepat Indonesia China.

\section{Berita Online sebagai Media Pembelajaran Berbasis Teknologi Digital}

Media pembelajaran merupakan sarana bagi siswa untuk memudahkan pemahaman terhadap materi pelajaran di sekolah. Gagne mengemukakan bahwa media pembelajaran yaitu berbagai jenis komponen dalam lingkungan siswa yang dapat merangsangnya untuk berpikir (Triyanto, 2013). Fungsi utama media pembelajaran adalah sebagai alat bantu mengajar yang turut mempengaruhi iklim, kondisi, dan lingkungan belajar yang ditata dan diciptakan oleh guru serta memiliki kegunaan seperti memperjelas penyajian pesan agar tidak terlalu bersifat verbalistis (hanya berupa kata atau lisan belaka), mengatasi keterbatasan ruang, waktu, dan daya indera sehingga proses belajar mengajar menjadi lebih bervariasi dan dapat menambah keaktifan siswa (Hasan, 2016:25).

Model pembelajaran yang kreatif dan inovatif perlu dikembangkan oleh pengajar untuk meningkatkan efektivitas dan efisiensi pembelajaran. Hal ini perlu dilakukan untuk menghilangkan kesan kurang menarik, monoton, dan membosankan dalam proses pembelajaran yang menghambat terjadinya transfer of knowledge (Muhson, 2010:45). Oleh karena itu, media pembelajaran yang kreatif dan inovatif sangat diperlukan dalam proses 
pembelajaran. Djamarah dan Zain mengemukakan bahwa media sumber belajar adalah alat bantu yang berguna dalam kegiatan belajar mengajar (Nugrahani, 2007:2). Alat bantu dapat mewakili sesuatu yang tidak dapat disampaikan oleh pengajar melalui kata-kata atau kalimat. Keefektifan daya serap siswa terhadap bahan pelajaran yang sulit dan rumit dapat dilakukan dengan menggunakan alat bantu berupa media pembelajaran yang sesuai dengan kondisi lingkungan siswa. Sehingga, kesulitan siswa memahami konsep dan prinsip tertentu dapat diatasi dengan media pembelajaran yang mudah diterima untuk melahirkan umpan balik yang baik dari anak didik dan meningkatkan minat belajar siswa.

Pengajar harus mampu membuat atau menentukan media pembelajaran yang sesuai dengan kebutuhan siswa dan perkembangan zaman. Penggunaan media pembelajaran yang sesuai dengan situasi dan kondisi kekinian dapat membantu pencapaian keberhasilan belajar (Mahnun, 2012). Berita online mudah diakses oleh siswa sehingga menjadi sarana yang dapat digunakan sebagai media pembelajaran di sekolah. Oleh karena itu, judul berita online dapat digunakan sebagai media pembejaran bagi siswa, khususnya terkait dengan materi tentang tindak tutur direktif. Judul berita online dapat digunakan sebagai contoh materi berita yang terdapat dalam pelajaran Sekolah Menengah Pertama dan sederajat Kelas VII sebagai Kompetensi Inti dan Kompetensi Dasar (KIKD) 3.1, 3.2 dan 4.1. 4.2.

\section{SIMPULAN}

Berdasarkan hasil dan pembahasan yang disajikan di atas, maka disimpulkan sebagai berikut. Pertama, tindak tutur direktif dalam berita online meliputi 9 (sembilan) jenis, yaitu: (1) memaksa, (2) memohon, (3) meminta, (4) memberi perintah, (5) menuntut, (6) melarang, (7) menyarankan, (8) mengajak, dan (9) menagih. Kedua, tindak tutur direktif dalam judul berita online dapat digunakan sebagai media pembelajaran di sekolah. Jenis tindak tutur direktif dalam berita online merupakan sarana media pembelajaran di sekolah berbasis teknologi digital.

\section{DAFTAR PUSTAKA}

Ardiansyah, E. A., Indrayani, L. M., Riyanto, S. 2014. "Jargon Pereta yang Dibentuk melalui Proses Perluasan Makna." Humaniora, 26 (3): 328-336.

Ananda, dkk. 2015. "Bentuk dan Fungsi Tindak Tutur Slogan Varian Iklan Pond's di Televisi". JJPBS, 3 (1): 1-12.

Basuki, Rinto Agus. 2013. "Tindak Tutur Menolak dalam Bahasa Jawa pada Masyarakat Jawa di Surakarta." Jalabahasa. 9 (2): 1-14.

Falahudin, Iwan. 2014. "Pemanfaatan Media dalam Pembelajaran." Junal Lingkar Widyaiswara, 1 (4): 104-117.

Handono, dkk. 2013. Pemakaian Bahasa Indonesia dalam Propaganda Politik. Balai Bahasa Jawa Tengah.

Hardini, Isriani. 2014. "Analisis Pragmatik dalam Wacana Kampanye PolitikPemilihan Gubernur dan Wakil Gubernur Jawa Tengah Periode 2013-2018.” Jurnal Penelitian, 11 (2): 301-316.

Hasan, Hasmiana. 2016. "Penggunaan Media Audio Visual Terhadap Ketuntasan Belajar IPS Materi Perkembangan Teknologi Produksi, Komunikasi, dan Transportasi pada Siswa Kelas IV SD Negeri 20 Banda Aceh.” Jurnal Pesona Dasar, 3 (4): 22-33. 
Ibda, Hamidulloh. 2018. "Penguatan Literasi Baru pada Guru Madrasah Ibtidaiyah Dalam Menjawab Tantangan Era Revolusi Industri 4.0." JRTIE: Journal of Research and Thought of Islamic Education, 1 (1):1-21.

Ibrahim, Abdul Syukur \& Suko Winarsih (2012). "Disorder Pragmatik Anak Tuna Rungu dalam Interaksi Pembelajaran di Kelas.” Jurnal Litera, 11 (2): 180-188.

Kusmanto, Hari. 2019. "Tindak Tutur Ilokusioner Deklaratif pada Wacana Berita PEMILU 2019: Studi Politikopragmatik." Jurnal Kata, 3 (1): 34-49.

Mahnun, Nunu. 2012. "Media Pembelajaran (Kajian terhadap Langkah-langkah Pemilihan Media dan Implementasinya dalam Pembelajaran)." Jurnal Pemikiran Islam, 37 (1): 27-35.

Mahsun. 2013. Metode Penelitian Bahasa: Tahapan, Strategi, dan Teknik. Jakarta: Raja Grafindo Persada.

Manaf, Abdul Ngusman. 2011. "Kesopanan TindaK Tutur Menyuruh dalam Bahasa Indonesia." Litera, 10 (2): 212-225.

Mardikantoro, Bakti Hari. 2014. "Analisis Wacana Kritis pada Tajuk Anti Korupsi di Surat Kabar Berbahasa Indonesia.” Litera, 13 (2): 215-225.

Muhson, Ali. 2010. "Pengembangan Media Pembelajaran Berbasis Teknologi Informasi." Jurnal Pendidikan Akutansi Indonesia, 8 (2): 1-10.

Nadar, FX. 2009. Pragmatik \& Penelitian Pragmatik. Yogyakarta: Graha Ilmu.

Nirmala, Vita. 2015. "Tindak Tututr Ilokusi pada Iklan Komersial Sumatra Ekspress". Kandai, 11 (2): 139-150.

Nugrahani, Rahina. 2007. "Media Pembelajaran Berbasis Visual Berbentuk PermainanUlar Tangga untuk Meningkatkan Kualitas Belajar Mengajar di Sekolah Dasar.” Lembaran Ilmu Pendidikan, 36 (1): 36-44.

Prayitno, Harun Joko. 2017. Studi Sosiopragmatik. Surakarta: Muhammadiyah University Press.

Purba, Atilan. 2011. “Tindak Tutur dan Peristiwa Tutur.” Pena, 1 (1): 77-91.

Qomariyah, Lailatul. 2017. "Tindak Tutur Direktif Guru dalam Pembelajaran Bahasa Arab." Arabia, 2 (1): 1-18.

Ratnasari, E. D., \& E. E. Edel. 2017. "The Illocutionary Acts in the Novel 'and the Mountains Echoed' By Khaled Hosseini." Jurnal KATA, 1(1): 15-23.

Rohmadi, M. 2014. "Kajian Pragmatik Percakapan Guru dan Siswa dalam Pembelajaran Bahasa Indonesia." Jurnal Paedogogia, 17 (1): 53-61.

Safrihady dan Hari Bakti Mardikantoro. 2017. "Jenis dan Fungsi Pragmatis Tindak Tutur Masyarakat Melayu Dialek Sambas di Kota Singkawang." Seloka, 6 (1): 59-67.

Sobur, A. 2015. Analisis Teks Media Suatu Pengantar untuk. Analisis Wacana, Analisis Semiotik, dan Analisis Framing. Bandung: PT Remaja Rosdakarya.

Sudaryanto. 2015. Metode dan Aneka Teknik. Analisis Bahasa. Yogyakarta: Duta Wacana UP.

Tarigan, Henri Guntur. 2009. Pengajaran Pragmatik. Bandung: PenerbitAngkasa.

Triyanto, Eko., Sri Anitah, dan Nunuk Suryani. 2013. "Peran Kepemimpinan Kepala Sekolah dalam Pemanfaatan Media Pembelajaran sebagai Upaya Peningkatan Kualitas Proses Pembelajaran."Jurnal Teknologi Pendidikan, 1 (2): 226-238.

Wiranty, Wiendi. 2015. "Tindak Tutur dalam Wacana Novel Laskar Pelangi Karya Andrea Hirata (Sebuah Tinjauan Pragmatik)." Jumal Pendidikan Bahasa, 4 (2): 294-304.

Yule, G. 2014. Pragmatik. Yogyakarta: Pustaka Pelajar. 